\title{
The Demand and Supply Imbalances in Blended Learning at the Arab Open University-Kuwait
}

\author{
Chekra Allani and Hassan Sharafuddin
}

\begin{abstract}
There is a growing demand for higher education in Kuwait in all the academic institutions. However, the blended learning system of education enjoys a greater appeal and the demand for it has been growing at a fast rate. In the meantime, the potential of the supply is lagging behind in meeting this growing demand. The aim of this paper is to provide an analysis of the factors that influence the demand for and the supply of higher education at the AOU. STEEP Analysis will be conducted whereby the regional dynamics that affect demand and supply will be discussed. Finally, some figures, strategies and case studies to resolve the imbalance problem will be provided and trends in blended learning at the AOU will be reviewed followed by a summary of trends in factors that affect the demand and supply. The final section is consecrated to findings and recommendations for future perspectives that inform policymakers to resolve supply and demand imbalances.
\end{abstract}

Index Terms - Blended learning, demand \& supply, e-learning, open learning.

\section{INTRODUCTION}

Higher education is increasingly transforming the whole world in general and the Middle East in particular. Today, there are over 400 universities in the Arab world - 10 times more than 40 years earlier [1]. Throughout this period, dramatic growth in higher education has been observed either in the number of students enrolled or in the campuses, classrooms, labs, libraries, etc. In the meantime, the population growth of the Arab world augmented and it is estimated to be around 380.4 million in 2015. Most of Arab countries' populations have similar characteristics. However, Gulf countries with less population growth are facing an increase in expatriates such as Bahrain, Kuwait, Qatar and Arab Emirates. This engenders an increase in demand for higher education.

This increase in population is forcing the demand for higher education and due to the rising cost of education and the low per capita income; most of the Arab students are not able to pay the tuition fees. One of the most important solutions to meet the demand for higher education is what is called open-learning or blended learning. The Arab Open University adopts the latter. It is a leading university in the Arab world that has 8 branches in different Arab states: Kuwait, Saudi Arabia, Jordan, Bahrain, Egypt, Lebanon, Oman and Sudan where the students' enrollment is increasing annually. Therefore, this paper is going to discuss the factors that influence the demand for higher education at

Manuscript received August 13, 2013; revised October 29, 2013.

The authors are with Arab Open University, Kuwait (e-mail: sharafh@aou.edu.kw).
AOU and the means to cater for this demand.

\section{RATIONALE}

There is an increasing demand for higher education at the AOU-Kuwait branch. In the meantime, the supply side cannot cope with this incremental augmentation. What are the factors that create this imbalance? How can this anomaly in demand and supply be overcome? This paper responds to these questions and proposes appropriate recommendations.

\section{Methodology}

The major functions of educational activities are primarily social, economical and political. Therefore, one of the appropriate tools to analyze the factors affecting demand and supply of higher education at AOU is STEEP analysis assuming that AOU cannot operate without being influenced by and impacting upon the external environment. These will include the five headings of sociological, technological, economic, environmental and political factors [2].

This methodology will also consider the classification set by Sarpkaya (2010) as a base in determining the external environment [3]. Socio-cultural factors include gender, age, ethnicity, vocation and prospects, technological factors have to do with technological revolution that started the past two decades and is still in progress; whereas economic factors comprise tuition fees, the coup de vie and market needs. As for the environmental aspects, these consist of the entourage as a whole; while the political factors encompass education system and the government's support.

\section{REVIEW OF LITERATURE}

Education is the most important tool to fight illiteracy, particularly in developing countries. Therefore, governments are allocating handsome budgets to handle the setback of illiteracy as a first objective in meeting human basic needs. Stromoquist (2005) sees that literacy development is a vehicle for decision-making, personal empowerment and participation in local and global social community [4]. Most of the developing countries, in general and Arab countries in particular, have been witnessing a rapid growth in population to the extent that they cannot cope with the increasing demand for educational needs. In other words, the formal system of education failed to fulfill educational needs of the people and, therefore, one of the solutions to solve such costly challenges is to introduce web-based education [5].

Online education, distance education or blended education is not new to higher education. Statistical reports show that 
most institutions in USA, for instance, continue to state that there is increasing competition for online students. One of this evidence is that over 5.6 million students were taking at least one online course during the fall 2009 term; an increase of about one million students over the number reported the previous year [6].

On the other hand, Allien and Simon show that " $75 \%$ of academic leaders at public institutions report that online is as good as and at times better than face-to-face instruction (compared to only $55.4 \%$ of private nonprofits and $67 \%$ of for-profit)" [7]. This evidence shows that there are some signs for an increasing competition for online tuition in USA. The same result can be applicable upon other regions in the world.

Definitions among the different types of online education are plenty. However, in our paper, we are going to follow Allen and Seaman (2010) in adopting their latest definition of Online Courses where at least $80 \%$ of the curriculum is delivered online, while face-to-face lectures comprise courses in which only zero to 29 percent of the content is delivered online. The remaining alternative, blended (sometimes called hybrid) instruction is defined as having between 30 percent and 80 percent of the course content delivered online [8]. Arab Open University in Kuwait is placed within the last definition where over 30 percent of the course content is delivered online. This policy was adopted as a response to the local validation set by the Ministry of Higher Education in Kuwait where higher education must have at least $75 \%$ of face-to-face teaching.

The demand for higher education, as shown above, is incrementally increasing and the mix of face-to-face with online learning is getting the lion share among other types of learning because of the produced learning outcome. This evidence has been found in USA through the publications of the United States Department of Education entitled Evaluation of Evidence-Based Practices in Online Learning: A Meta-Analysis and Review of Online Learning Studies. The report clarifies that "The overall finding of the meta-analysis is that classes with online learning (whether taught completely online or blended) on average produce stronger student learning outcomes than do classes with solely face-to-face instruction" [9].

\section{THE DEMAND AND SUPPly FOR Higher EDUCATION}

AOU-Kuwait receives more than 3000 students a year who seek enrollment but due to some supply factors, AOU-Kuwait accepts a limited number of these students. For example, the table below shows that the number of students enrolled at AOU-Kuwait has been fluctuating in spite of the incremental rise in demand. According to Admission and Registration department, some 3000 applicants seek enrollment at Kuwait Branch each academic year out of which only half are admitted [10]. To create a balance between the local private universities in terms of students' enrollment, higher education officials in Kuwait capped the number of admittance at the AOU. Had it not been for this cap, figures in Table I below would have been on the ascending. The imbalance lies in the growing demand as opposed to the lower supply creating a deprivation of many expatriates to pursue their higher education. The main reason for not being able to accept more students is the relative resistance to open learning from local higher education authorities. This view is incrementally fading away.

TABLE I: STUDENTS ENROLLMENT AT AOU

\begin{tabular}{|c|c|}
\hline Academic Year & Enrolled Students \\
\hline $2006 / 7$ & 5619 \\
\hline $2007 / 8$ & 5394 \\
\hline $2008 / 9$ & 4701 \\
\hline $2009 / 10$ & 5085 \\
\hline $2010 / 11$ & 4638 \\
\hline
\end{tabular}

There are several factors, which the authors feel, are responsible for increasing the demand for blended learning at the AOU-Kuwait. These factors are Social, Technological, Economical, Environmental and Political factors.

- Social Factors

Unlike other universities in the region, AOU students represent a myriad of ethnic and age groups and a greater proportion of female students. Kuwait has population diversity which demographic documents record $45 \%$ of Kuwaiti nationals and 55\% expatriate [11]. Kuwait University, the only public university in the region, cannot cater for the thousands of applicants each academic year. Therefore, admission became restricted to Kuwaiti citizens with higher GPAs.

Out of 12.000 applicants, Kuwait University's capacity of enrollment is no more than 6.500 students [12]. Therefore, many expats and a fewer Kuwaitis joined the private universities that commenced their operations the past decade. These are Arab Open University (AOU), Gulf University of Sciences and Technology (GUST), American University of Kuwait (AUK) and American University of Middle East (AUM).

The AOU with its blended learning system attracts higher demand. Less than half of these students are Kuwaitis, and the remaining are expatriates of over 40 ethnic groups. AOU students are in fact the non-traditional type, since a major ratio of those students is working full time mothers who thrive to complete a degree to upgrade their professional status. These students are not all fresh high school graduates, as it is quite common to encounter three generations in an AOU tutorial: The Millennial, the Gen-X and the Boomer [13].

The technologically driven millennial students have grown up with mobiles, laptops; i-pods etc... and are more enticed by blended learning than older generations who try to keep pace in order not to find themselves alienated in their new educational system. Besides, parents knew the value of education and are determined their children should acquire a higher education and boast of educational achievement and of the dual certification offered by the AOU. Unlike the Veblen good which concords the quality with the price, the AOU boasts quality and subsidized fees.

- Technological Factors

The past two decades created a shift in education paradigm. With the technological revolution and the knowledge 
explosion, a new conceptual era emerged. Art Levine stated three strategic visions of the university: "Brick university, click university and brick and click university, which is a hybrid of the first two" [14]. The literature goes even further as to speculate the fading away of traditional universities altogether within the next 30 years. (Cunningham et al., 2002). At the AOU, the learner benefits from face to face tutorials where synchronous communication occurs between tutor and learner and between peers in a brick and mortar campus. The students also benefit from a cutting edge technology that is constantly being updated by professional technicians to facilitate the curriculum delivery and to communicate with their tutors and students from the eight campuses.

The new application of technology is preceded by inductions to tutors who in turn act as facilitators in the learning process. Web-based learning tools and students' forums provided an interaction between learner and content, learner and tutor and peer learning. Technology is therefore the catalyst of this pedagogical shift in education. The flexibility and practicality of this learning process gave it great popularity. It is no wonder that the AOU, Kuwait Branch has the lion share of students' enrollment in Kuwait. Technology is being used to reach not only off-campus students, but also to interact with the eight branches in the neighboring AOU host countries. The demand for blended learning is continuously growing. In a survey conducted by Schell (2001), he finds that the majority of students opt for blended learning to be able to balance their multiple commitments. Had it not been for the technological revolution, this shift of education paradigm could not have taken place.

\section{- Economical Factors}

The most enticing factor that attracts students to enroll at AOU-Kuwait is its tuition fees. There is only one public university in Kuwait which accepts mainly Kuwaiti citizens to enroll in it. Therefore, a number of private universities have emerged during the last seven years and offer different programs to the expatriates as well as to Kuwaiti citizens. However, AOU is the only university which supplies higher education with economic fees. These fees range from 20 to 30 percent of other private universities tuition fees. Unlike other private universities, the AOU's philosophy is in providing higher education to all individuals in the society with subsidized fees. It is therefore a non-profit higher educational institution [15]. This factor is the most important one that plays an important role in increasing the demand for education at AOU-Kuwait.

Another important economic factor is the income. Although studies concerned with human capital show that education costs have substantial effect on income, this issue is still hotly debated and controversies prevail the literature. Kuwait, as the Fig. 1 shows, is the second country, after UAE among the five Gulf countries in terms of per-capita income [16]. Hence, this increase in individual income encouraged Kuwaiti citizens to enroll at AOU-Kuwait.

Non-Kuwaiti citizens have gained an increase in income as well through the increase in GNP and the stability of the consumer prices. This stability encouraged the expatriates to enroll at AOU-Kuwait to obtain a certificate in higher education while continuing to provide services in the labor market. Therefore, income rising and the stability of the purchasing power became an important factor not only to seek education for graduate studies but also for post graduate studies.

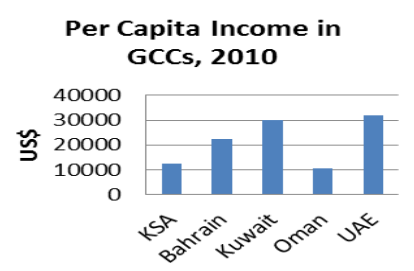

Fig. 1. Magnetization as a function of applied field.

The third economic factor has to do with the Kuwait strategic project in developing Kuwait into a regional financial center. This project is supported by the political stability, free flow of capital, prime geographic location and the highly efficient banking and financial system. Whether this project is going to be implemented now or later, prospectors expect that this strategic project will create derived demand on higher education for graduate and post graduate studies. Having two certificates one from the ministry of Higher education in Kuwait and another one from Open University in UK will construct further demand for higher education at AOU during the next five years to meet the requirement for graduates in the labor market.

- Environmental Factors

The environment of the new millennium is quite inducive to blended learning, be it in academic or business institutions. Due to the abundance of knowledge that is acquired from many channels, today's learner is more mature, disciplined and quite adapted to the less structured environment of blended learning. Born with i-phones and i-pads and laptops, the millennial has the capacity to overcome the anxiety and confusion that might stem from technical difficulties. This high-tech environment renders students inductions minimal and gives a relative autonomy.

\section{- Political Factors}

The political factor pushes the demand for education. The development of countries necessitates not only natural resources but the man power that is qualified and quantified to meet the development and market needs. The governments in the AOU host countries donate lands to have university campuses built and laws are to ease local validations. Several AOUs' branches have their own non-rented buildings such as Kuwait, Jordan and Egypt and this, in turn, will give AOU solid ground in terms of institutional accreditation resulting in more demand for higher education at AOU.

One of the most important issues in terms of political factors is that AOU has succeeded in establishing a universal academic institution in different Arab countries and there is a plan to establish further branches in other countries. The authors feel that this step will curb some of the political conflicts that might arise among some of Arab countries and develop the academic practices towards one university. Having this in mind, Arab students prefer to study in a country with similar curriculum so when they return to their home countries, their certificates are validated. They can moreover continue their higher education in Europe with the 
OU certification. This, in turn, has led to an increase in the demand for higher education at AOU.

\section{CONCLUSION}

This study can be considered as an induction to the AOU staff members to grasp the factors that influence the international trends in blended learning and the social, technological, economic, environmental and political factors that affect the demand and supply at the AOU-Kuwait. The paper provided the most important factors that show the increasing importance of blended learning worldwide. These factors can be used as a basis for convincing Higher Education officials in the eight AOU host countries to speed up local validation.

Within the rapid changes that are happening in the socio-economic, technological and political arenas, it is high time for higher education officials to cope with and to recognize these catalysts of pedagogical paradigm shift. It is hoped that this study acts as a stimulus for the recognition of the eight branches of each others' diplomas in the first place.

It is also intended to persuade the Private University Council in Kuwait to lift the cap off the limited number of enrolled students at AOU Kuwait Branch. Endogenously, the AOU is able to meet this demand and to create a balance between the demand and supply, hadn't this exogenous factor hindered the supply.

The AOU has a noble mission of offering higher education with subsidized fees that can sustain its growth with no profit. The authors look forward to the support of higher education officials in Kuwait to raise the quota of students' enrollment at the AOU Kuwait Branch in order to give a chance to all those candidates who have been applying for years to fulfill the dreams of their life.

\section{REFERENCES}

[1] Arabic Report for Cultural Development. (Sep. 28, 2011). First Report. [Online]. pp. 43. Available: http://www.arabthought.org/en/node/407

[2] D. Preston et al., "For more details about STEEP model, 'What is Business'," An Introduction to Business Studies, The Open University, Walton Hall, UK, pp. 16-20, 2006.

[3] R. Sarpkaya, "Factors Affecting Individual Education Demand at the Entrance to University: Adnan Menderes University Sample," Kuram ve Uygulamada Egitim Bilimleri, vol. 10, no. 1, 1 Oct. 2011.
[4] N. Stromoquist, "Gender and literacy development," in D. A. Wagner, R. L. Venezky, and B. V. Street (eds.), Literacy: An international Handbook. Boulder, Colo: Westiew Press, 2005.

[5] M. M. Ansari, Economics of Distance Education, New Delhi: Concept Publishing Company, pp. 25-26, 1992,

[6] I. E. Allen and J. Seaman, Class differences: Online education in the United States, The Sloan Consortium, Babson Survey Research Group, pp. 2, 2010.

[7] I. E. Allen and J. Seaman, Class differences: Online education in the United States, The Sloan Consortium, Babson Survey Research Group, pp. 3, 2010.

[8] I. E. Allen and J. Seaman, Class differences: Online education in the United States, The Sloan Consortium, Babson Survey Research Group, pp. 5,2010 .

[9] United States Department of Education, "Evaluation of Evidence-based Practices in Online Learning: a Meta-analysis and review of online learning studies," U.S. Department of education, Office of Planning, Evaluation, and Policy development, Washington, DC. 2009 , pp. 6.

[10] AOU-Kuwait, Statistical Report, Quality Assurance Unit, Kuwait, 2011.

[11] Kuwait Demographics Profile 2011, September 17, 2011.

[12] A. D. A. Tamimi, "Kuwait and the Development of Instruction to Meet the Market Needs," Al Hayat London's Paper, August 18, 2011

[13] C. Dziuban, P. Moskal, and J. Hartman "Higher Education, Blended Learning and the Generations: Knowledge is power, No more," September 20, 2011.

[14] S. O. Ikenberry, Higher Education and Market Forces, August, 14 2011.

[15] AOU, $3^{\text {rd }}$ Strategic Plan 2017-2012, AOU, the Head Quarter, pp. 5.

[16] Economy. [Online]. Available: http://economyofkuwait.blogspot.com/2010/02/2030_3448.html

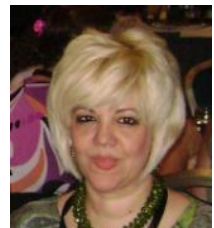

Chekra Allani is an assistant professor at the Arab Open University, Kuwait Branch. She is from Tunisia and pursued her studies in Illinois, USA and in Sana'a Yemen where she got her PhD in English Literature in 2006. She is currently the coordinator of the English Language and Literature Program at the Arab Open University and is a prolific institutional researcher and reviewer in blended learning topics.

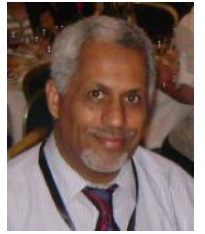

Hassan Sharafuddin is a lecturer at the Arab Open University. He is from Yemen, born in 1956.The author got his master degree in economic development from Vanderbilt university at Nashville Tennessee, USA, 1981 and his $\mathrm{PhD}$ in Economics from Cairo university, Cairo, Egypt in 1990. He is working now as an assistan professor at Arab Open University - Kuwait. He worked at Sana'a University as a dean during the period 2003-2006 and published several researches in refereed journals. 